to be studied. The wider study in which the authors are involved over the next 2 years seeks to address some of these questions.

A final issue is the often-neglected small pockets of women with multiple vulnerabilities. These are the women who fall outside of the adult and average intelligence patient population located in predominantly male mixed-gender units. The higher risk of vulnerability for those women who are under 21 years or over 60 years or who have learning disabilities is still to be considered, and as we move towards redistributing adult women patients into single-gender units we must be careful not to neglect these 'minority' groups within the women's secure population.

\section{Limitations of the study}

The telephone survey was chosen as the least disruptive and most efficient method of collecting the data. The data may have some inconsistencies because it was up to our contact person's discretion to check the accuracy of the data that they provided. Also, the survey spans a 6 month period: there may be a few women patients who were either discharged or admitted during the course of the survey. However, because the average length of stay in a medium secure unit is 18-24 months, it is unlikely that there was much patient turnover.

The authors acknowledge the limitations in this form of collecting data but note that there are few data in this area. The future reporting of Department of Health, Home Office and institutional survey statistics by gender would be most useful.

\section{Acknowledgements}

The authors wish to thank all of the units that participated in the telephone survey and the High Security Psychiatric Services Commissioning Board for funding the study, of which this survey is a small part. They also extend thanks to Liz Mayne, Director of WISH, for her comments on a draft of this paper.

\section{References}

DEPARTMENT OF HEALTH (2000) Secure Futures for Women: Making a Difference (Chairman: Dame Rennie Fritchie). London: High Security Psychiatric Services.

EASTMAN, N. GHANDI, E. \& BELLAMY S. (2001) Admission Criteria to Secure Services and Service Definitions. Report to the Department of Health. London: Department of Health.

HIGGO, R. \& SHETTY, G. (1991) Four years' experience of a regional secure unit. Journal of Forensic Psychiatry, 2 202-210

HOME OFFICE \& DEPARTMENT OF MENTAL HEALTH AND SOCIAL SECURITY (1975) Report of the Committee on MentallyAbnormal Offenders (Butler Report). Cmnd 6244. London: HMSO.

JAMIESON, E., BUTWELL, M., TAYLOR, P., et al (2000) Trends in special (highsecurity) hospitals. British Journal of Psychiatry, 176, 253-259.

*Yonette Hassell Research Psychologist, Annie Bartlett Senior Lecture and Consultant in Forensic Psychiatry, Forensic Psychiatry, St George's Hospital Medical School, JennerWing, CranmerTerrace, London SW17 ORE
MADEN, A. (1996) Women, Prisons and Psychiatry: Medical Disorder Behind Bars. Oxford: Butterworth Heinemann.

MILNE, S., BARRON, P., FRASER, K., et al (1995) Sex differences in patients admitted to a regional secure unit. Medical Science Law, 35, 57-60.

MURRAY, K. (1996) The use of beds in NHS medium secure units in England. Journal of Forensic Psychiatry, 7, 504 524.

RAMPTON HOSPITAL (1998) Forensic Director (3rdedn) Retford, Nottingham: Rampton Hospital. SPECIAL HOSPITALS SERVICE AUTHORITY (1995) Service Strategies for Secure Care. London: SHSA.

\title{
On being in a young offender institution: what boys on remand told a child psychiatrist
}

\author{
AIM AND METHOD \\ To describe the reported experi- \\ ences of 15- and 16-year-old boys \\ on remand in a young offender \\ institution (YOI) as told to a child \\ psychiatrist. Nineteen remanded \\ adolescents were interviewed \\ using the Kiddie-Schedule for \\ Affective Disorders and \\ Schizophrenia as part of a study. \\ During the warm-up conversation \\ prior to this semi-structured \\ interview, the boys were given the \\ opportunity to talk about their \\ experiences of being in a YOI.
}

\section{RESULTS}

The boys described experiences of institutionalisation, including the deprivation of incarceration and the intimidation of a 'macho-culture', which on occasions verged on the abusive. Their responses are described.

\section{CLINICAL IMPLICATIONS}

An emotionally deprived prison environment that lacks appropriate care for children is likely to contribute to the very high levels of mental disorder known to exist in this popu lation. A major reform of conditions for young prisoners has commenced since this study was conducted. The prison service and society as a whole must, however, ensure that the planned improved living conditions for children in prison are reached. Child psychiatry has a very important contribution to make by providing mental health care within prison institutions in order to engage young prisoners with mental health problems and their families. 
Over recent years there has been a large increase in the number of children remanded in prison custody. During 1999, 521 young people age 15 and 1159 age 16 were received into prison on remand in England and Wales (Home Office Research \& Statistics Directorate, 2000). This paper examines the experiences of 19 boys on remand in the juvenile wing of a young offender institution (YOI) as described in their stories told to one of the authors, a visiting senior registrar in child psychiatry (C.D.)

\section{Method}

Seventeen male remand prisoners aged 16 years and two aged 15 years were interviewed using the KiddieSchedule for Affective Disorders and Schizophrenia (K-SADS; Ambrosini, 2000) to ascertain the level of mental disorder. Results of this study are published separately (available from the authors upon request). The $\mathrm{K}-\mathrm{SADS}$ interview is preceded by unstructured conversation aimed to establish positive rapport. What the boys said was noted contemporaneously and reconstructed immediately afterwards. These notes formed the basis of the following thematic analysis (Glaser \& Strauss, 1967).

Ten of the young people interviewed were Black; eight of these were born in the UK. Eight had a history of being 'looked after' by the local authority for more than 1 year. All except one, who had been studying for his A-levels, had been excluded from mainstream school. Nine boys were charged with acquisitive offences, four with robbery, two with rape and four with grievous bodily harm, trespass, supply of drugs and conspiracy, respectively.

\section{Themes}

When given the opportunity to speak freely, a consistent theme that emerged during the unstructured part of the interview centred around the boys experiences of their living conditions and the difficulties of being imprisoned.

\section{Incarceration}

Many boys described being locked in their cells for very long periods of time. For boys not receiving education and during weekends, claims of spending up to 23 hours per day in cell were not uncommon. The other hour was spent in 'association', colloquially referred to as 'Soc.', when the boys can play pool, watch television, make phone calls and are expected to have a shower. During the period of the study, all meals were eaten by the inmates while locked up in their cells. All the boys stressed the effect of being locked up for so long in their cells. A typical comment was "I feel depressed because I'm banged up for 23 hours, pacing around". They often said that either they or others "can't handle their bang up", resulting in "screaming, radios on loud, tapping on the pipes". An application or 'App' given to the prison officer needed to be granted for the boys to attend gym and for those above school leaving age to attend educa- tion. Most boys appeared preoccupied with the granting or refusal of 'Apps', as the mechanism that modified the time spent in 'bang-up'.

\section{Pervasive routines and unknown rules}

"It's the same thing every day, it gets on my nerves, the same thing over and over," said one boy. While routines appeared pervasive, the rules were often unclear. Many of the boys reported not being informed of the rules and routines on admission, thus initially missing out. One boy said he did not know why he had been placed on 'basic', a more restricted regime. He reported asking three prison officers but not finding out. Not knowing the rules concerning visiting resulted in failed visits - one boy reported that after a long journey his mother was not allowed to visit because she had a different surname and he hadn't put a visitor's order in. A boy wearing prison clothes reported that his own clothes brought in by his father had been in reception for 5 days. Because he did not understand about the 'box system' he was not allowed them until his father visited again.

\section{Physical deprivation}

Some of the boys reported that the cells were cold at night, which disturbed their sleeping: "it's freezing cold, the window is closed but it wobbles". One boy reported that his request for an extra blanket had been unsuccessful. Many of the boys commented on the food, frequently reported as 'horrible'. Some said that they were 'starving' and had lost weight because there was insufficient to eat. A few who were depressed had lost their appetites. Several of the boys reported that they had not been able to have regular showers: "didn't have a shower for 2 weeks, felt dirty, they only let me have one just before court. Meant to have showers during Soc. but at school". Another boy reported not having a shower for 10 days, despite having eczema and needing to use creams.

\section{Peer conflict}

Despite physical isolation within the cell, the boys could hear each others' presence much of the time. Indeed the noise of shouting and singing out of windows, of the hitting of the heating pipes which run from one cell to another and of blasting radios was heard throughout the YOI. The boys described verbal abuse occurring commonly, "people cuss you a lot more on the inside because you can't get to them". Much verbal abuse denigrated mothers "they run each others' mothers off, it's a prison thing". One boy reported that he often avoided association because "if I go out someone might wind me up, they say things about your mum - your mum's a slut, suck your mum". Verbal abuse was often reported to be followed by physical challenges, "they make them sing out the window - twinkle, twinkle, little star, or I'll get you".

The boys reported fights occurring frequently "about 10 during the last $4-5$ days". One boy said "it's 
sometimes noisy at night, everyone knows if there's going to be a fight the next day". One boy said "you don't walk away from a fight" others said that they could not "be bothered" to get into fights. Regarding who is bullied, "new boys who look like they can't fight. Even little boys bully big boys". "Fraggles [parlance for psychiatric patient] get bullied, they don't speak up, don't fight back, quiet, let themselves get bullied". One boy reported that he was avoiding association because other boys had demanded that he hand over his cigarettes and snacks. He said "I'm not bothered, they can only punch me a few times before it's broken up. If they kill me, it's their life they've ruined. I hope they punch my face, not ribs, as they're already sore".

\section{Mutual 'wind-up' with staff}

Some boys referred to persistent provocation by staff: "screws very provocative - imitate you, mimic you. Take the piss - opened the door after association and said I forgot about you". Another boy said the prison officers were "okay sometimes, at other times sarcastic", for instance when stressing they were going home. Another boy said "a couple of officers take the piss: talk like an African". One boy reported a prison officer saying to him "see you tomorrow" when he was going to court and "you'll never get out".

The boys reported dealing with the provocation in different ways. Some said that they ignored it because they depended on the prison officer to let them have showers or phone calls. Others reacted, "if they say things to me I'll say things to them". One boy said that he would call them "failed policeman" and ask if they had "failed their tests". Boys referred to being 'stitched up' by prison officers, by which they meant being blamed unfairly. One boy said that he had thought of harming himself after being 'stitched up' by a prison officer. Several boys described how, in contrast to the current remand wing, social work staff in secure units and prison officers on sentenced wings within the same YOI 'cared' about them, inferred by the way they were spoken to.

\section{Abuse by staff}

Two boys independently reported experiences from another YOI where institutionalised 'wind-up' appears to have led to systematic intimidation by prison staff. They alleged that while they were held in the segregation unit officers insisted that they run along 'blue lines' to get their meals: if they did not run fast enough or did not stay on the lines officers would punch them. They said that these same officers "were different on the wings", where the boys were not subjected to such treatment.

\section{Nobody thinking of them}

The boys described isolation from their families, as if nobody was thinking or caring for them. Some of the boys had not received any visits, "my mum said she wouldn't visit if I came back to prison". Another boy looked tearful when he told me that since being in prison he had written quite a lot to his mother but that she had not written back.

One boy reported that 10 days previously when he had been helping with distributing tea, a cell door was opened to reveal someone trying to hang themselves. The prison officer who was with him told him to return to his cell while he sought help. No subsequent check was made to determine whether this experience had adversely affected him. He was relieved to learn by rumour that the youth had not succeeded in killing himself. He did, however, suffer from persistent traumatic flashbacks following the incident.

\section{Coping strategies}

A number of different coping strategies were described. One boy reported that when he had to spend long periods locked in his cell he would "punch the walls" when he got angry; another said he was on 'basic' regime for banging on the cell door. The implication was that self-inflicted pain helped them cope with being locked in cell, despite the consequences. A few of the boys appeared to utilise complex mechanisms of denial to cope with the reality of their situations. They did not participate in gym or Soc., as they believed in immediate release. They planned to tell friends and relatives about where they were only after the next court date. Others coped by spending a lot of time thinking of loved ones, including mothers, who had been absent for much of their lives. For others it was too painful to think about their families, "my mother didn't want me. I can't think about my father it upsets me too much".

A lot of emotional energy was often invested in relationships with girlfriends. One boy who had no contact with his parents said that he was kept going by thoughts of his girlfriend; the relationship was of 3 weeks' duration, for 2 of which he had been in custody! Much time was spent thinking about 'getting out' and making plans about what they would do when released: "visit my mates, go to the pub, have a MacDonald's and go for a long walk". The longer term plans were vaguer, usually to go to college or get a job.

\section{Discussion}

The boys interviewed in this study described a range of adverse experiences, including spending up to 23 hours a day locked up in a cell, bullying by peers, humiliation from some staff and denial and false hopes about families. Some boys gave the impression of never having told their stories before; particularly those who wanted to portray themselves as 'hard'. Others were clearly distressed and angry about the conditions they reported.

Do these reported experiences represent expression of the anger and frustration of some young people remanded to prison who have been given the 'ear' of a sympathetic listener or do they represent true experiences? The clarity and consistency of the boys' reports gives weight to the validity of their descriptions. Similar findings have also been reported in a subsequent study in 
which 58 young people in 10 prisons participated in focus groups that included their experiences of being in prison (Lyon et al, 2000). The thematic report by the Chief Inspector of Prisons also identified similar concerns as those reported by the young prisoners in this study (HM Chief Inspector of Prisons, 1997).

Four officers have now been suspended in relation to identical allegations of mistreatment in the YOI named by the two boys in this study (Guardian, 5 August 2000).

While it is important to point out that this study was carried out in a YOI that is now recognised to have been in severe crisis, the conditions described are not unique and the themes, in less extreme form, are prevalent throughout the young offender estate. It is clear that subjecting children to these conditions is detrimental to both their development and mental health.

The factors that lead to this unacceptable situation are complex. They include: the incarceration of children in a prison system primarily designed to hold adults; gross lack of resources both in terms of capital and the appropriate training and support of prison staff; and the challenges posed by the children themselves. The prison service has begun to address these problems by setting down new and appropriate standards of care for young prisoners (Prison Service, 1999).

Children in prison constitute one of the most socially and psychologically deprived and needy young populations in society. It is the responsibility of the prison service, Youth Justice Board and ultimately of the Home Secretary and society that the improved living conditions set out in the new prison standards are implemented in full. However, psychiatric services also have a very significant contribution to make. The report of the joint working party (Prison Service \& NHS Executive Working Group, 1999) requires the NHS to work in partnership with the prison service to provide mental health care in prison.
To date, child and adolescent mental health services have been notable by their absence from institutions holding prisoners under the age of 18 years. Child psychiatrists working in prison can contribute to the health and welfare of young people and give direction and support to prison staff. In conjunction with this, the development of health participation in local authority youth offender teams provides an opportunity for locally based mental health professionals to facilitate links by working with boys and girls remanded in prison custody and afterwards back home.

\section{References} England and Wales 1999. London:
AMBROSINI, P. J. (2000) Historical development and present studies of the schedule for affective disorders and schizophrenia for school-age children (K-SADS). Journal of the American Academy of Child and Adolescent Psychiatry, 39, 49-58.

GLASER, B. G. \& STRAUSS, A. L. (1967) The Discovery of Grounded Theory: Strategies for Qualitative Research. Chicago: Aldine

HM CHIEF INSPECTOR OF PRISONS (1997) Young Prisoners: A Thematic Review. London: Home Office.

HOME OFFICE RESEARCH \& STATISTICS DIRECTORATE (2000) Prison Statistics Stationery Office.

LYON, J., DENNISON, C. \& WILSON, A. (2000) Home Office research study 201 'People in Custody. Tell Them So they listen': Messages from Young People in Custody. London: Prison Service.

PRISON SERVICE (1999) Order no. 4950. Regimes for Prisoners Under 18 Years Old. London: Prison Service.

- \& NATIONAL HEALTH SERVICE EXECUTIVE WORKING GROUP (1999) The Future Organisation of Prison Health Care. London: Department of Health.

* Claire Dimond Senior Registrar in Adolescent Forensic Psychiatry, Forensic Mental Health Services, Shaftesbury Clinic, Springfield University Hospital, 61 Glenburnie Road, London SW17 7DJ, Peter Misch Consultant Adolescent Forensic Psychiatrist, Children's Department, Maudsley Hospital, London SE5 8AZ, David Goldberg Consultant Adolescent Psychiatrist, The Adolescent Service, 32 York Road, Battersea, London SW11 3QJ

\section{E. JAN WISE AND JAMES P. WATSON}

\section{Postal survey of psychiatrists' knowledge and attitudes towards driving and mental illness}

\section{AIMS AND METHOD}

We assessed psychiatrists' knowledge and attitudes towards the Driver and Vehicle Licensing Agency (DVLA) regulations concerning mental illness. A postal survey of all consultant and trainee psychiatrists (228) on the South Thames (East) regional psychiatry rotation was carried out.

\section{RESULTS}

For category 1 (private car and motorcycles) licenses, $40.0 \%$ of psychiatrists could correctly advise patients with a bipolar affective disorder; this figure was $0 \%$ for schizophreniform disorders. For category 2 (heavy goods vehicles) licenses the corresponding figures were $13.2 \%$ and $11.8 \%$, respectively.
For alcohol misuse, alcohol dependency and alcohol related disorders, the scores were $26.0 \%, 29.1 \%$ and $19.7 \%$.

\section{CLINICAL IMPLICATIONS}

Psychiatrists fail to know or apply existing DVLA regulations, for a number of reasons. Failure to inform patients of the restrictions and to record this may result in medico-legal liability for practitioners. original papers 